\title{
The level of social relations comprehension and its impact on text comprehension in individuals with autistic spectrum disorder
}

\section{BACKGROUND}

The study was carried out within the research "Reading comprehension - typical development and its risks". The article contains data from a component study focused on $4^{\text {th }}$ grade students with autism spectrum disorder (ASD) who were incorporated into a group of readers with reading comprehension development risks. The main aim was to establish whether variable results in children's reading and comprehension tests relate to the level of understanding of social relations.

\section{PARTICIPANTS AND PROCEDURE}

We tested 20 students with ASD in two phases: T1 and T2. Each phase consisted of 2 individual sessions. Under the leadership of a research assistant, during each of these sessions a student would carry out the test focused on general intellectual skills, language skills, reading, and reading comprehension. For students with autistic spectrum disorder the Strange Stories test was added in order to ascertain the level of social relations understanding.
RESULTS

The results in reading and reading comprehension tests among students with ASD varied significantly. Based on a correlation analysis it was found that the Strange Stories results substantially correlate with tests focused on reading, text comprehension and language skill levels.

\section{CONCLUSIONS}

Our research proved the following: the Strange Stories test results show that the level to which an individual is able to understand social relations and social behavior is significantly related to his/her ability to comprehend a text. Consequently, this can influence his/her learning skills as well as the quality of life in society. Cultivation of social abilities, social communication and understanding of social situations and relations is therefore necessary for compensation of autistic spectrum disorder expressions.

\section{KEY WORDS}

reading comprehension; autistic spectrum disorder; social relations comprehension; reading disorder; simple view of reading 


\section{BACKGROUND}

Reading and reading comprehension are among the basic skills necessary for the successful existence of an individual in school and later in society. This is also one of the reasons why such attention is being paid to this topic in both Czech and international research (see Hulme \& Joshi, 1998; Kucharská, 2014; Perfetti, 1985; Snowling, 2000; Wildová, 2012 and others), not only from the perspective of the development of reading skills, but also with regard to the potential risks related to the development of reading literacy in specific groups. One of these groups comprises individuals with autism spectrum disorder (ASD), especially students with Asperger syndrome and high functioning autism.

As mentioned above, the present research study was part of the "Reading comprehension - typical development and its risks" project, which focused on the definition and exact description of individual and development connections, and the course of the development of reading comprehension in children in the first to fourth grades of elementary school. Additionally, it concentrates on the monitoring of risk factors within groups of fourth graders (involving children with learning disabilities, specific language impairment, ASD, and poor readers). We based our project on the simple reading model (Gough \& Tunmer, 1986), which allowed for the inclusion of all of the above-mentioned groups of readers. This model of reading with comprehension is based on the assumption that in order to successfully master reading, an individual needs the development of reading comprehension patterned on two areas, the first one being decoding (reading level) and the second one being listening comprehension. A simple equation then applies (Kirby \& Savage, 2008):

$$
\mathrm{RC}=\mathrm{D} \times \mathrm{LC} \mathrm{RC},
$$

where RC - reading comprehension, D - decoding, LC - listening comprehension.

This pattern describes reader groups on the basis of their results in both areas, hence making it possible to characterize individuals and to compare or analyze their reading level and reading comprehension. Therefore, it includes children with typical development whose decoding and comprehension progress together, as well as children with various reading issues, e.g. learning disabilities, a specific language impairment, or autism spectrum disorder, or poor readers.

In the methodological phase of the project we were aware of the fact that the simple model has certain limits. To cover the topic of reading and its development in its full complexity it was necessary to take into account other aspects as outlined by Perfetti, Landi, and Oakhill (2005). They published a model of factors influencing the development of reading comprehension consisting of the following key areas: - the general skills area (which can be related to IQ), which predominantly enables text navigation, context comprehension based on experience, etc.,

- the linguistics area, which includes phonological, syntactic, and morphological awareness,

- the lexicological area, which includes word meaning comprehension and some levels of syntactic and morphological awareness,

- the orthographic units interconnection area (graphemes, spelling...) and corresponding pho-

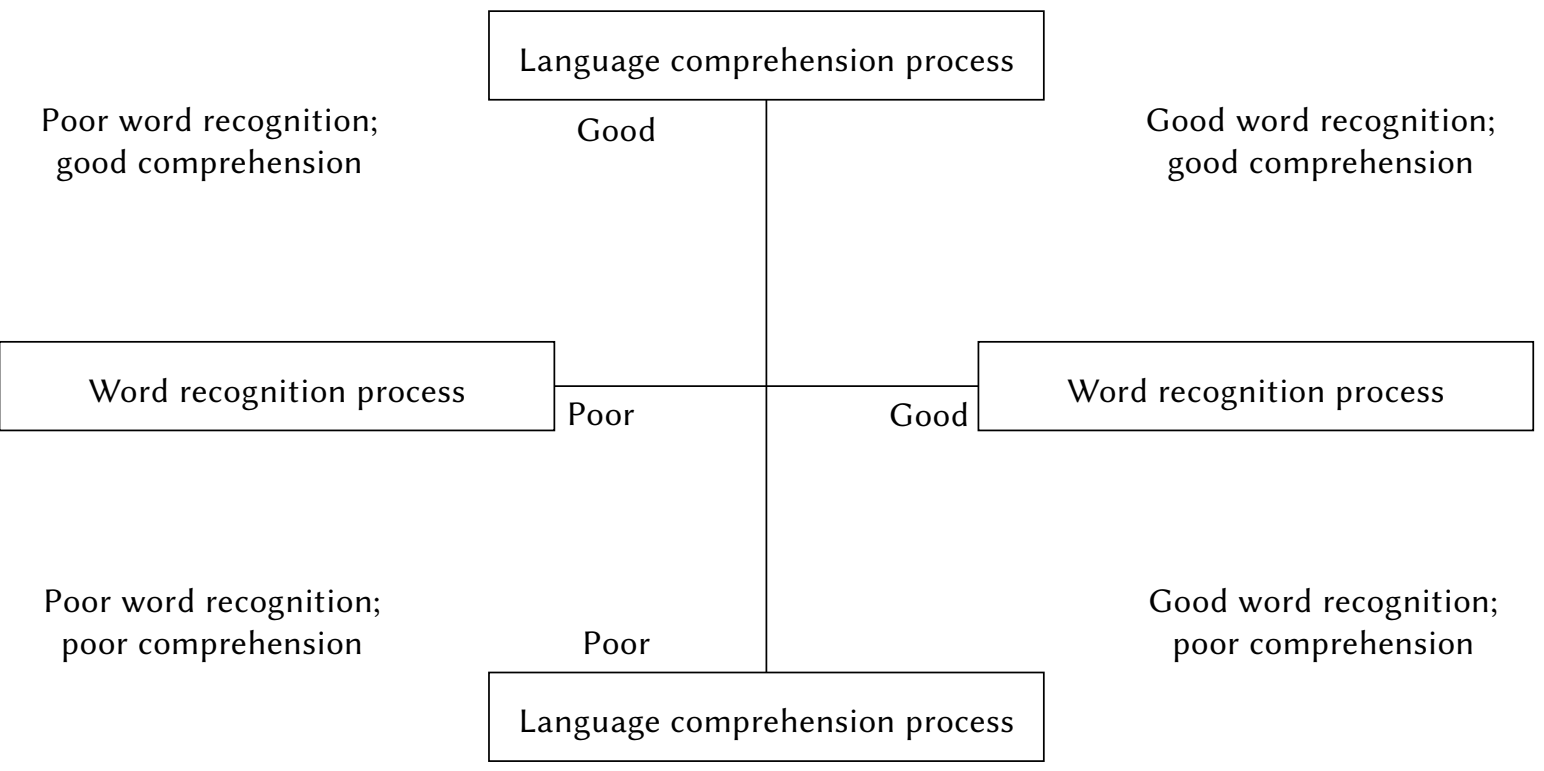

Note. From http://www.specialneedsdigest.com/2013/03/helping-struggling-reader-how-readers.html

Figure 1. Simple view of reading model. 
nological units, hence the area linked to decoding skills (Perfetti et al., 2005).

According to these authors, reading comprehension skills increase with the repetition of reading experience and general language experience, which develops in the preceding phases mainly in connection with listening comprehension. Williamson, Carnahan, and Jacobs (2012) point out that decoding is mainly significant at the start of education. Muter, Hulme, Snowling, and Stevenson (2004) confirm this conclusion in their research, establishing that in the early stages of the development of reading abilities, decoding determines the success rate of reading comprehension. As they claim, in the next phase (at about seven years of age, although it can vary according to the start of formal education), in addition to decoding, the level of vocabulary and grammatical (morphological and syntactic) skills determines the development of reading comprehension. Kirby adds that more complex cognitive processes, e.g. top-down processes, gradually become more fundamental for comprehension later on. These processes allow the determination of the potential content based on the topic only; this subsequently has an impact on lower processes - all the way to the precision with which words are read. Since we wanted our research to cover factors impacting on reading comprehension in their full complexity, we reflected on the above-mentioned facts when drawing up the set of tests.

Within the simple model of reading, individuals with ASD are included in a group of individuals with strong decoding but poor comprehension. Although bibliographies tend to link the usual profiles of individuals to particular disorders (e.g. Catts, Adlof, \& Weismer, 2006), particular groups display internal output variabilities and within that variability they can overlap (Bishop \& Norbury, 2002; Ricketts, 2011). On the basis of the application of the model we may state that the reason why a group of individuals with ASD fails or is at risk in reading is that it shows a significant discrepancy between results in the area of decoding and at the level of listening comprehension. This was also confirmed by the research studies quoted in the next section. Although some researchers suggest that decoding in individuals with ASD is not always at the same level as we can find in typically developing children (Nation, Clarke, Wright, \& Williams, 2006), it is still significantly higher than comprehension. These conclusions have been corroborated by other studies (e.g. Huemer \& Mann, 2010; O’Connor \& Klein, 2004).

It is indicative of the fact that it is mainly the linguistic and lexical areas that are problematic in children with ASD. These individuals often show delayed or disrupted speech development, although even children without significant deviation from the norm in their speech development encounter problems in the area of lexicology. As a result of the disrupt- ed perception of social relations and social behavior (Thorová, 2006), their ability to understand the meanings of words and contextualization does not develop in the same way as that of their intact peers. Consequently, reading comprehension starts to fail in a child whose speech development was not significantly damaged and who decodes very well. Norbury and Nation (2011) studied the impact of language skills on reading comprehension. They found that adolescents with ASD comprehension performance differ substantially in terms of their language skill levels. Wahlberg and Magliano (in Huemer \& Mann, 2010) explain that the issues related to understanding of individuals with autistic spectrum disorder relate to a limited ability to provide relevant background to a text, set into context. The whole picture of comprehension difficulties is depicted by O'Connor (O'Connor \& Klein, 2004), the conclusions of whose study claim that children with high functioning ASD do not show considerable problems understanding particular words, but start doing so at the sentence level. In tests where children were asked to put a word into a sentence in accordance with its meaning, an irrelevant, albeit grammatically correct, meaning was often chosen. This reflects the fact that the children understood the grammatical side of the language, but were not able to appreciate the sense of the sentence.

There is research-based evidence that a child's language proficiency shows a substantial correlation with his/her social ability and skills. Because of their different cognitive information processing, children with autism have disordered socialization skills (e.g. Thorová, 2006; Baron-Cohen, Leslie, \& Frith, 1985; Ricketts et al., 2013; O'Hare, Bremner, Nash, Happé, \& Pettigrew, 2009). The study "Theory of mind" (Baron-Cohen et al., 1985) proved that individuals with ASD have problems in comprehension and distinguishing the mental states of others. This subsequently leads to deficits in empathy, comprehension of social situations and relations, or social communication (Baron-Cohen, in Thorová, 2006). Happé (1994) furthered this theory by creating a so-called second/higher-grade theory of mind tests (known as "Strange Stories"), assessing comprehension of social situations, the situational context, jokes, and puns. Ricketts et al. (2013) verified whether performance levels in theory of mind tests can be one way to analyze problems in reading comprehension. In their research they analyzed a simple model of reading in adolescents with ASD. One hundred adolescents aged 14-16 were observed; their listening comprehension and word recognition were analyzed, and social skills tests were added. The results support the given reading model. The subjects' speech comprehension and decoding directly impacted on reading comprehension. However, when the quoted variables were controlled, the pattern variability depended on the performance in theory of mind tests and under-
Social relations comprehension and text comprehension in individuals with $A S D$ 
standing of social relations. We proceeded with our research taking this into account. Certain Strange Stories test items were included in the set of tests for children with ASD. We were determined to find out whether the results in this test would correlate with the results for language skill, reading, and reading comprehension tests. In the next part we introduce the concept of our test and its results.

Hana Sotáková, Anna Kucharská

\section{AIM OF THE STUDY}

In the present study we focused on specific features of reading comprehension in children with ASD. We are interested in the relationship between understanding of social behavior (situations) and reading comprehension. Therefore we decided to conduct a correlation study involving a theory of mind task (Happé, 1994) and reading and linguistic tests (Sotáková et al., 2014). Another objective was to describe types of reading comprehension profiles in children with ASD.

\section{PARTICIPANTS AND PROCEDURE}

\section{PARTICIPANTS}

Our study targeted fourth-grade students with a clinical diagnosis of autism spectrum disorders (ICD-10). The research involved a total of 20 children ( 16 boys and 4 girls) from across the Czech Republic. Given the relatively narrow definition of the criteria for inclusion in the study, the demographic distribution of the research participants was random, but children from cities and towns and villages were represented. All the children were integrated as special needs students in mainstream elementary schools. The average age of the students was 129 months $(S D=7.18)$, which is older than the average age of fourth-grade students in general. This is possibly due to the fact that students with ASD often start their schooling a year later in the Czech Republic ${ }^{1}$ (one student in our group started his schooling with a two-year delay, which is possible only for pupils with special educational needs).

Informed consent of the child's legal caregiver, a clinical diagnosis of ASD (verified using the CAST screening questionnaire), and maintaining the level of intellectual abilities were the criteria for including the child in the study.

\section{PROCEDURES}

The data were collected in two individual sessions conducted by especially trained assistants. We divided the sessions according to the time and level of difficulty of the tests. During the testing we always respected the child's personal tempo and needs. Each session lasted 90 to 120 minutes (so that every child had enough time to process the tasks), and we administered selected standardized and experimental tests targeting complex skills important for reading comprehension. The testing took place in a quiet room set in a building in the school the student attended. The tests used in the individual sessions are presented in Table 1. We included the Strange Stories test in the second session for pupils with ASD. Our aim was to determine whether the children's performance on this test would show statistically significant correlations with the other tests of reading comprehension and language level.

\section{MATERIALS}

Reading (Decoding)

We assessed the child's decoding level as the basic precursor of reading comprehension. We used two standardized measures: the One minute reading test and Nonword reading test, both from the Set of diagnostic tests of literacy skills for students of the $2^{\text {nd }}-5^{\text {th }}$

Table 1

Measures administered in session one (T1) and session two (T2)

\begin{tabular}{cc}
\hline T1 & T2 \\
\hline $\begin{array}{c}\text { One minute reading } \\
\text { RAN (rapid automatic naming) } \\
\text { Strange Stories } \\
\text { Spoonerism }\end{array}$ & $\begin{array}{c}\text { Nock Design (WISC IV) } \\
\text { Little Star }\end{array}$ \\
The Reading Comprehension Test \\
(Caravolas \& Volín, 2005) \\
Morphological awareness - sentence \\
Picture Vocabulary
\end{tabular}


grade (Caravolas \& Volín, 2005). The One minute reading test consists of 140 words drawn up in three columns on two sides of an A4 sheet. The words proceed from the easiest (in terms of phonetic structures) and shortest words to more difficult words. The task of the child is to read as many words as he/she can in one minute. The correct answer is considered to be the number of correct words read in the time limit.

The Nonword reading test contains 24 nonwords (three sets of eight words) that respect the phonotactic rules of the Czech language. The words have increasing difficulty, and the child is asked to read as quickly and as well as possible. The test is not limited in time, but time is measured and recorded. A correctly read word scores one point.

\section{TEST COMPREHENSION MEASURES}

With the text comprehension tests we were targeting several aspects that may affect the performance of children. That is why we included all tests - listening comprehension, reading aloud comprehension, and silent reading comprehension. There were not enough standardized tests of these aspects available in the Czech Republic; therefore we created new experimental tests and combined them with a standardized measure (see the description below).

The Reading Comprehension Test is a standardized test of silent reading comprehension (Caravolas \& Volín, 2005). Children are asked to put words into phrases on the basis of the meaning of the sentence. The test consists of 20 test tasks. Each task includes two sentences in which each sentence is always missing one word. The children choose one word from a menu of five available words. They have seven minutes to select the appropriate words from a prepared worksheet. One point is scored for each correctly completed word in every sentence. In total, the child can earn up to 40 points.

Listening comprehension was examined with the Little Star test (Kucharská \& Mrázková, in Kucharská et al., 2014). The test consists of a fairy-tale-style story (recording) and a set of 12 questions to determine the comprehension of the story. The questions are focused on the main story line and also details. We score for accuracy and/or the completeness of responses ( 0,1 , or 2 points).

The reading comprehension test (reading aloud) was called Rabbits. The test consists of a text and a worksheet with 12 related questions to determine the understanding of the story. We also follow the quality of decoding (such as fluency, dual reading, etc.). The child reads the text and the administrator tracks errors in reading and the number of words read in the first, second, and third minutes, and the total time. After that the child is asked to answer the set of 12 questions.

\section{LANGUAGE}

Among the tests of the child's language skills, we included an experimental test, Picture Vocabulary (Seidlová Málková \& Smolík, 2014). This test evaluates the extent of the child's receptive vocabulary. It consists of 36 cards, each with four pictures. Each card belongs to one target word. One of the images on the card always represents the target word. The other three images are distractors with a meaning more or less (un-)related to the target word. For each correctly specified image a child acquires one point.

The phonological skills of the children were assessed by means of the standardized tests Rapid automatic naming (RAN - numbers; in Caravolas et al., 2012) and Spoonerism. In RAN the child has to quickly identify numbers $(2,3,6,7,9)$ from a table on cards, which alternate in quasi-random order. There are five rows with eight numbers on the card. Each number on the card is repeated eight times. The child works with a total of two cards. We measure the time in seconds required to finish a set of numbers. We also record the number of errors.

Spoonerism (Caravolas \& Volín, 2005). The test consists of 10 pairs of nonwords respecting the phonotactic rules of the Czech language. The first two pairs of words are two-letter words; others consist of three letters (CVC: consonant, vowel, consonant). The task of the child is first to isolate the initial sound of each nonword and then to swap and thus transpose these initial sounds. For example, the pair "kin-gas" should be transposed to "gin-kas". The child's task is to repeat the pair of nonwords and then pronounce a new pair with transposed initial sounds. The limit for a response is 20 seconds. We evaluate correctly transposed sounds. The children can earn up to 20 points.

Morphological awareness - word (Kucharská \& Šmejkalová, in Kucharská et al., 2014). The test has two parts. Both parts are divided into four blocks according to the specific grammatical feature. Each block contains five test items based on the same grammatical principle (e.g. formation of adjectives, grammatical number, grammatical gender). Initial training is performed before each block. The child is asked to answer questions that are read aloud. Each correctly answered item is awarded one point. The total score is obtained by adding together the points gained for all the blocks.

Morphological awareness - sentence (Kucharská \& Šmejkalová, in Kucharská et al., 2014). The test has the same structure as the previous one. Each block includes five test items based on the same grammatical principle. In Blocks 1 and 2 we examine the child's ability to determine the correct form of the sentence. Blocks 3 and 4 then focus on the child's ability to determine the correct meaning of the sentence. The total score is obtained by adding together the points gained for all the blocks.
Social relations comprehension and text comprehension in individuals with $A S D$ 


\section{SOCIAL SKILLS - STRANGE STORIES TEST}

In the Czech Republic there is no standardized measure that could be used for the diagnosis of social skills and understanding of social relationships in children with ASD. The Strange Stories test is indeed known but is not commonly used. It usually depends more on the experience and approach of each psychologist if he/she works with it. Therefore, we decided to use Strange Stories test items from the O'Hare et al. (2009) research study conducted to verify the test for the general population of children. Given that we included the test as one part of the test battery, it was necessary to reduce the number of items used. That is why we selected and included a total of six items (see Appendix 1), which we translated into Czech. We made sure that the content matched the original items exactly.

The examiner introduced the test by saying: "Here are some stories and some questions. I am going to read you the stories. I want you to listen carefully and then answer the questions.” The story was then read aloud to the child. Then the child was asked the first question: "Is it true what XY says?". With the first question we examined whether the child understood the story. We repeated the question if the child so required, hesitated, or answered incorrectly. The second question, "Why does XY say that?", observed whether the child was able to understand the mental state of the people in the story. If the child was able to describe only the physical state (what happened in the story, what the response was), we awarded one point; for describing the mental condition of the people the child was given two points. If the child was not able to answer in even one of these ways, the answer did not explain the events in the story, or the child answered "I do not know", then zero points were gained. The assessment was recorded and evaluated by two independent examiners in order to obtain accurate data.

\section{RESULTS}

We decided to present the findings of our research in three parts. The first part introduces the result scores of all the tests of the children with autistic spectrum disorder. Table 2 shows that the results were very individual. However, in general, our research showed that there is a major difference between the results of the decoding tests and the reading comprehension tests, as we described earlier on. Decoding tends to be the strong skill of ASD children, whereas the reading comprehension results have a tendency to be worse. However, this does not mean that the result scores of the decoding tests are always high. We can observe this in the large difference between the One Minute Reading test and the Nonword reading test.

We observed differences not only in the test result scores but also in the work behavior of the children, as well as in their working focus and emotional stability. Some of the children found it difficult to con-

Table 2

Descriptive information on standardized and experimental measures

\begin{tabular}{|c|c|c|c|c|c|}
\hline \multirow[t]{2}{*}{ Test } & \multirow[t]{2}{*}{$n$} & \multirow[t]{2}{*}{ M } & \multirow[t]{2}{*}{$S D$} & \multicolumn{2}{|c|}{ Range } \\
\hline & & & & $\min$ & $\max$ \\
\hline Block Design & 20 & 10.20 & 2.86 & 4.00 & 15.00 \\
\hline Strange Stories & 20 & 8.50 & 2.90 & 0.00 & 11.00 \\
\hline $\mathrm{RAN}^{*}$ & 20 & 20.80 & 3.70 & 15.50 & 28.00 \\
\hline Picture Vocabulary & 20 & 30.00 & 1.41 & 11.00 & 31.00 \\
\hline Spoonerism & 18 & 12.10 & 5.05 & 2.00 & 18.00 \\
\hline Morphological awareness - sentence & 19 & 13.20 & 3.54 & 2.00 & 17.00 \\
\hline Morphological awareness - word & 20 & 25.15 & 9.88 & 1.00 & 36.00 \\
\hline One minute reading & 20 & 85.05 & 18.34 & 50.00 & 113.00 \\
\hline Nonword reading & 19 & 17.00 & 6.33 & 7.00 & 24.00 \\
\hline $\begin{array}{l}\text { The Reading Comprehension Test } \\
\text { (Caravolas \& Volín, 2005) }\end{array}$ & 19 & 5.68 & 8.78 & 5.00 & 36.00 \\
\hline Little Star & 20 & 10.15 & 4.46 & 3.00 & 16.00 \\
\hline Rabbits & 19 & 10.80 & 4.30 & 3.00 & 18.00 \\
\hline
\end{tabular}

Note. ${ }^{*}$ Time results in seconds. 
trol their behavior and four of the respondents required the presence of a personal assistant.

\section{RESULTS PROFILE COMPARISON ${ }^{2}$}

The second part of our findings is based on the test result profiles of the children with ASD. We created the profiles because of the differences we described earlier. On the basis of the results, we were able to divide the children's profiles into three main groups. Below we show particular examples of the most represented profiles in children with ASD. In order to provide a better understanding of the variation found in the group of children with ASD, we added an average profile of a group of typically developing children $(N=134)$. The data for typically developing children (the TD group) is based on the parallel research study of the fourth graders (Sotáková et al., 2014).

The first group includes children with generally higher result scores than the average score of the typically developing children. As Figure 2 shows, their results were higher in all the tests than the average results of intact fourth graders. To conclude, we can say that these children did not show any remarkable symptoms of the disorder. According to the clinical diagnosis, most of the children in this group were diagnosed with Asperger syndrome or high-functioning Asperger syndrome.

The second group comprised children who achieved imbalanced scores in the different tests. Even though some of their results were higher than the average results of the TD group, some of their result scores were worse. The biggest gap was discovered especially between the results of the decoding test and the reading comprehension tests. However, we found an interesting pattern of results in their morphosyntactical awareness (word) test. In the test, we assessed stu-

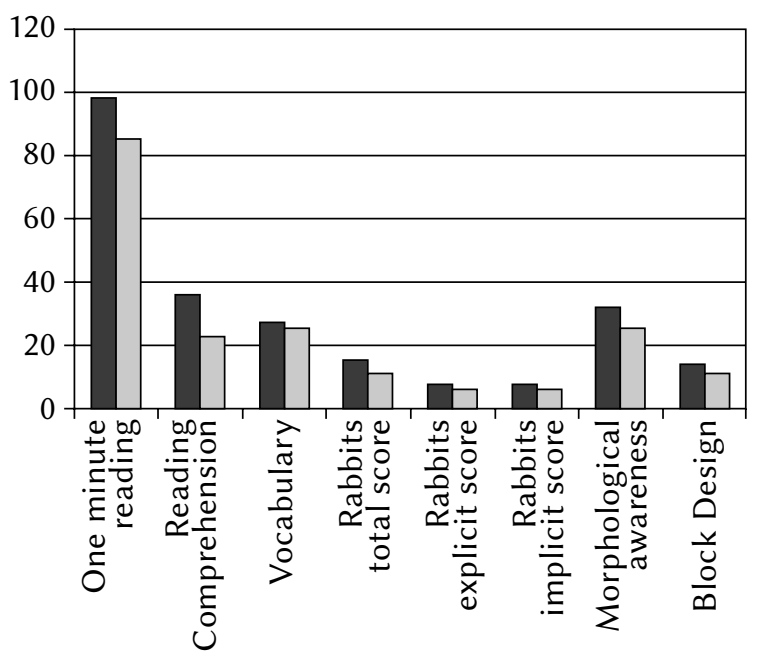

- Profile $1 \quad \square$ TD mean

Figure 2. Autism spectrum disorder - Profile 1. dents' understanding of grammatical principles. In the particular profile shown above, the score of the morphosyntactical task in the child with ASD was higher than the mean of the typically developing group. We assume that the higher result may be associated with the fact that Czech grammar has very organized rules and therefore some children with ASD do not encounter significant problems in the test. In conclusion, we observed that the second group mainly includes children with atypical ASD and Asperger syndrome.

The majority of the test result scores of the children in the third group were remarkably worse than the average results of the TD group. Only the Block Design test results of these children were better than the TD group results. These children struggled with language skills, social behavior, and adaptation to the test conditions. This group is also composed of children with behavioral problems and children who have a need for personal assistance. Two children found the adaptation to a new social situation extremely difficult, and we had to split their first sessions into two parts. As time progressed, they found it easier to adapt to the situation. This group consisted of one student with childhood autism, two students with atypical autism, and three children with Asperger syndrome.

To sum up, it is evident that we cannot assign a certain profile to autism spectrum disorder as there are many factors that influence the results. Some of these factors are: intellectual skills, the level of the symptoms of the disorder, the level of language skills, and the level of understanding of social interactions.

\section{LEVEL OF SOCIAL SKILLS AND READING COMPREHENSION}

A possible reason for the variability of test results is the different level of understanding of social inter-

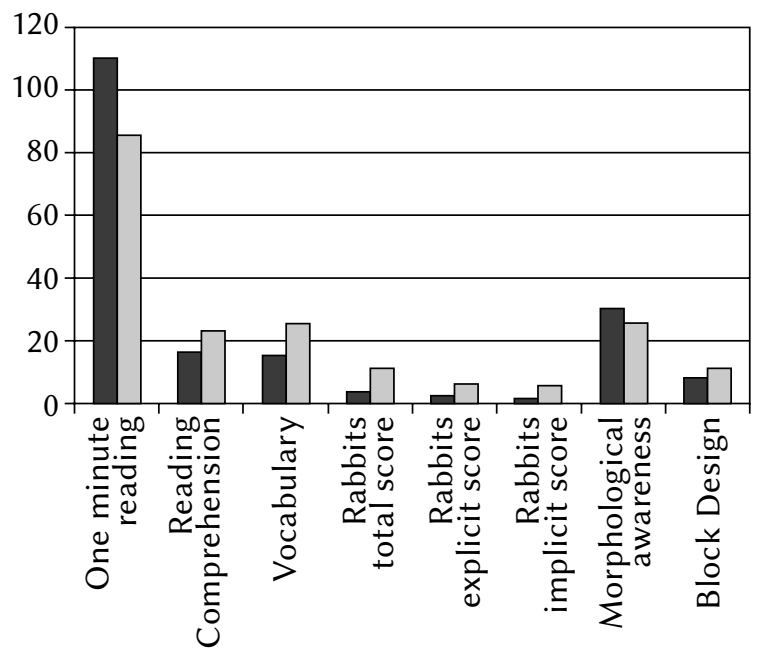

๑ Profile $2 \quad \square$ TD mean

Figure 3. Autism spectrum disorder - Profile 2.
Social relations comprehension and text comprehension in individuals with ASD 
Hana Sotáková, Anna Kucharská

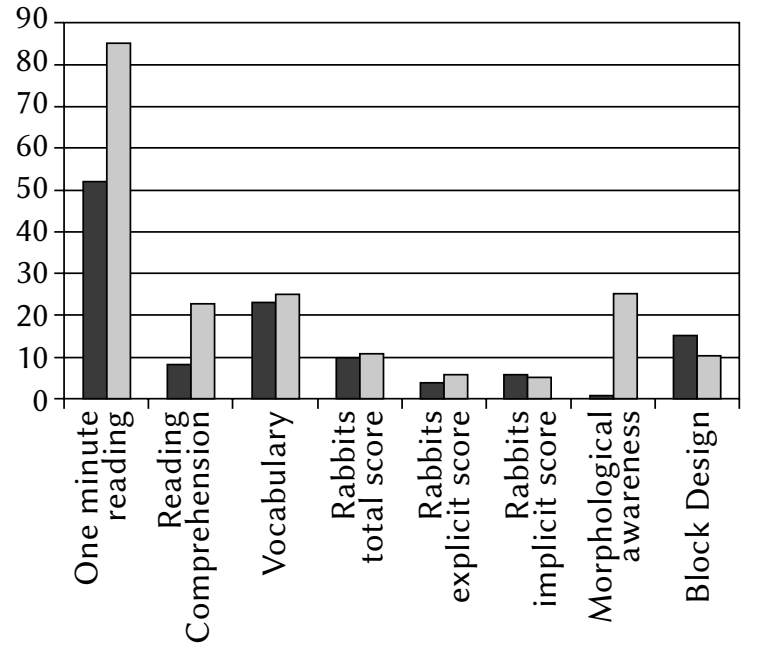

$\square$ Profile $3 \quad \square$ TD mean

Figure 4. Autism spectrum disorder - Profile 3.

actions that every child who was tested had. Considering our previous hypothesis, we compared the Strange Stories test results with the results of the comprehension and language tests in the third part of the study. We used correlation analysis to observe the relations between the test results of the Strange Stories test, reading comprehension tests, and the other tests from our set. Although we expected that the relationship between the Strange Stories and text comprehension tests would be confirmed, the strength of the correlation coefficient was surprising. We did not presume that there would be high values both in tests of reading comprehension and in the morphological awareness test. Neither did we expect such a remarkable correlation between the Strange Stories Test and the decoding tests (One minute reading and Nonword reading). From the results (see Table 3), we can assume that deficits in social skills and in understanding of social interactions are very important. Our research shows that they influence the literacy skills of a child and a lack of literacy skills influences not only children's school life but also their everyday life. On the other hand, we did not find any significant relationship between the Strange Stories test and the Block Design test results.

\section{DISCUSSION}

This article focused on children with ASD, and the results of the present study were similar to those that were observed in international research. Similarly to the results of O'Connor and Klein (2004) or Frith and Snowling (1983), our test results show a large gap between the scores achieved in the decoding test and the scores achieved in text comprehension tests. We also support findings that not all ASD children achieve high scores in decoding tests; however, their score results in decoding are generally higher than their score results in reading comprehension (Nation et al., 2006).

The results within the ASD groups showed variability for all measures. We obtained interesting findings, especially in the morphosyntactical tests. The children with ASD scored higher than the average of the TD group. We can assume that they are able to understand and apply grammatical rules even if they do not always understand the meaning of a word or a phrase. As we mentioned above, O'Connor and Klein (2004) obtained similar findings in their research focused on facilitation strategies for ASD adolescents. Unlike our children, their adolescents with ASD did not show gaps in their understanding of isolated words, but they struggled to understand the meaning of a sentence (in the test they were asked to use a word to fill in a gap in a sentence). Understanding a sentence is closely connected to understanding of social interactions, which these children often lack. Understanding of social interactions and understanding of the mental states of others is related to the Theory of Mind (Baron-Cohen et al., 1985). The theory shows that these understandings are important for language communication skills, as well as for reading comprehension. This fact is also reflected in the Diagnostic and Statistical Manual for Mental Disorders 5 (DSM-5), which was introduced in 2013. The manual revised the diagnostic criteria for the autistic spectrum and established new criteria joining social interactions with communication, as they are closely linked.

Our comparative analysis of the Strange Stories test and text comprehension tests confirmed a statistically significant correlation between the test re-

Table 3

Strange Stories test correlations

\begin{tabular}{lccccccc}
\hline & $\begin{array}{c}\text { Block } \\
\text { Design }\end{array}$ & $\begin{array}{c}\text { One } \\
\text { minute } \\
\text { reading }\end{array}$ & $\begin{array}{c}\text { Non- } \\
\text { word } \\
\text { reading }\end{array}$ & $\begin{array}{c}\text { Morphologi- } \\
\text { cal awareness } \\
- \text { word }\end{array}$ & $\begin{array}{c}\text { Reading } \\
\text { Compre- } \\
\text { hension Test } \\
\text { (Caravolas } \\
\& \text { Volín, 2005) }\end{array}$ & $\begin{array}{c}\text { Little Star } \\
\text { Listening } \\
\text { comprehen- } \\
\text { sion }\end{array}$ & $\begin{array}{c}\text { Rabbits } \\
\text { Reading com- } \\
\text { prehension }\end{array}$ \\
\hline $\begin{array}{l}\text { Strange } \\
\text { Stories } \\
\text { total }\end{array}$ & -.17 & $.51^{*}$ & $.47^{*}$ & $.46^{*}$ & $.64^{* *}$ & $.58^{* *}$ & $.50^{*}$ \\
\hline
\end{tabular}

Note. Spearman's coefficient, ${ }^{*} p<.05,{ }^{* *} p<.01$ 
sults for these two areas. This supports the research findings of Ricketts et al. (2013), who observed the relation between social skills and reading comprehension. On the other hand, we did not find any relation between the results of the Strange Stories test and the Block Design test. This is in agreement with the findings of Thorová (2006) and Wing and Potter (2002), who claim that the social skills of children with ASD do not depend on their intellectual skills, even though having average or above-average intellectual skills is one of the criteria of high-functioning autism.

In further study we would like to analyze the relationship between level of social skills, linguistic tests, and comprehension test results in detail and create a reading comprehension model involving social understanding.

\section{CONCLUSIONS}

The research was a part of the first large reading comprehension research study in the Czech Republic. We tested both the typically developing population and children who are at high risk of text comprehension problems. In conclusion, the level of social skills and the understanding of social skills seem to be the key factors for the lives of children with ASD. Problems in the development of social skills, as well as problems in the development of the understanding of social interactions, are a part of the ASD disorder. This means that we can find profiles of children who are extremely intelligent, but have problems with coping with ordinary school life and society.

Our research proved that social skills and understanding of social interactions are related to the results of the text comprehension tests (at all levels) and to the results of the linguistic tests. On the basis of all the results, we can say that the development of social intelligence is highly important for the development of literacy skills and for the improvement of the quality of life of children with ASD. We suggest that the academic curriculum for ASD children should involve training in social skills such as we can find, for example, in the Social Stories program (Gray, 2010). This curriculum will help children with ASD in their school life as well as in their ordinary life.

The article was financially supported by Czech Science Foundation. It is a constituent part of outputs of grant project for the Faculty of Education Charles University in Prague - "Reading comprehension - typical development and its risks” P407/13-20678S.

\section{ENDNOTES}

1 In the Czech Republic, postponement of school attendance can be granted on the basis of a psycho- logical assessment. The Ministry of Education of the Czech Republic states that in 2015 20\% of typically developing children had a postponement and $35 \%$ of ASD children had a postponement (from http:// www.msmt.cz/vzdelavani/skolstvi-v-cr/statistika-skolstvi/zapisy-do-1-rocniku-zakladnich-skol).

2 The profiles shown in Figures 1, 2, and 3 are profiles of particular children from our ASD group, which represent a group of the results profile.

\section{References}

Baron-Cohen, S., Leslie, A., \& Frith, U. (1985). Does the autistic child have a "theory of mind"? Cognition, 21, 37-46.

Bishop, D. V., \& Norbury, C. F. (2002). Inferential processing and story recall in children with communication problems: A comparison of specific language impairment, pragmatic language impairment, and high functioning autism. International Journal of Language and Communication Disorders, 37, 227-251.

Caravolas, M., \& Volín, J. (2005). Baterie diagnostických testů gramotnostních dovedností pro žáky 2. až 5. ročníků ZŠ [Diagnostics tests battery of literacy skills for children from 2 to 5 grades of primary school]. Praha: IPPP ČR.

Caravolas, M., Lervag, A., Mousikou, P., Efrim, C., Litavský, M., Onochie-Quantillas, E., Salas, N., Schöffelová, M., Defior, S., Mikulajová, M., Seidlová Málková, G., \& Hulme, C. (2012). Common patterns of prediction of literacy development in different alphabetic orthographies. Psychological Science, 23, 678-686.

Catts, H. W., Adlof, S. M., \& Weismer, S. E. (2006). Language deficits in poor comprehenders: a case for the simple view of reading. Journal of Speech, Language and Hearing Research, 49, 278-293.

DSM 5. From http://www.dsm5.org/Documents/Autism\%20Spectrum\%20Disorder\%20Fact\%20Sheet.pdf.

Frith, U., \& Snowling, M. (1983). Reading for meaning and reading for sound in autistic and dyslexic children. British Journal of Developmental Psychology, 1, 329-342.

Gough, P., \& Tunmer, W. (1986). Decoding, reading, and reading disability. Remedial and Special Education, 7, 6-10.

Gray, C. (2010). The new Social Story ${ }^{T M}$ book: Revised and expanded $10^{\text {th }}$ anniversary edition. Arlington, TX: Future Horizons.

Happé, F. (1994). An advanced test of theory of mind: understanding of story characters' thoughts and feelings by able autistic, mentally handicapped, and normal children and adults. Journal of Autism and Developmental Disorders, 24, 129-154.

Huemer, S. V., \& Mann, V. (2010). A comprehensive profile of decoding and comprehension in autism
Social relations comprehension and text comprehension in individuals with $A S D$ 
Hana Sotáková, Anna Kucharská spectrum disorders. Journal of Autism and Developmental Disorders, 40, 485-493.

Hulme, C., \& Joshi, R. M. (eds.). (1998). Reading and Spelling: Development and Disorders. Newark, NJ: Lawrence Erlbaum Associates.

ICD-10 R. From http://www.uzis.cz/cz/mkn/.

Kirby, J. R., \& Savage, R. S. (2008). Can the simple view deal with the complexities of reading? Literacy, 42, 75-82.

Kirby, J. R. What have we learned about reading comprehension. From http://www.edu.gov.on.ca/eng/ research/kirby.pdf.

Kucharská, A. (2014). Riziko dyslexie. Pregramotnostní schopnosti a dovednosti a rozvoj gramotnosti v rizikových skupinách [The risk of dyslexia. Preliteracy skills and literacy development in high-risk groups]. Praha: PedF UK.

Kucharská, A., Seidlová Málková, G., Sotáková, H., Špačková, K., Presslerová, P., \& Richterová, E. (2014). Porozumění čtenému I. Typický vývoj porozumění čtenému - východiska, témata, zdroje - kritická analýza a návrh výzkumu [Reading comprehension I. A typical reading comprehension development - background, topics, resources - critical analysis and research proposal]. Praha: PedF UK v Praze.

Muter, V., Hulme, C., Snowling, M. J., \& Stevenson, J. (2004). Phonemes, rimes, vocabulary, and grammatical skills as foundations of early reading development: evidence from a longitudinal study. Developmental Psychology, 40, 665-681.

Nation, K., Clarke, P., Wright, B., \& Williams, C. (2006). Patterns of reading ability in children with autism spectrum disorder. Journal of Autism and Developmental Disorders, 36, 911-919.

Norbury, C. F., \& Nation, K. (2011). Understanding variability in reading comprehension in adolescents with autism spectrum disorders: interactions with language status and decoding skill. Scientific Studies of Reading, 15, 191-210.

O'Connor, I. M., \& Klein, P. D. (2004). Exploration of strategies for facilitating the reading comprehension of high-functioning students with autism spectrum disorders. Journal of Autism and Developmental Disorders, 34, 115-127.

O’Hare, A. E., Bremner, L., Nash, M., Happé, F., \& Pettigrew, L. M. (2009). A clinical assessment tool for advanced theory of mind performance in 5 to 12 year olds. Journal of Autism and Development Disorders, 39, 916-928.

Perfetti, C. A. (1985). Reading Ability. New York: Oxford University Press.

Perfetti, C. A., Landi, N., \& Oakhill, J. (2005). The acquisition of reading comprehension skill. In M. J. Snowling, C. Hulme, \& M. Seidenberg (eds.), The science of reading (pp. 227-247). Oxford, UK: Blackwell.
Ricketts, J., Jones, C. R., Happé, F., \& Charman, T. (2013). Reading comprehension in autism spectrum disorders: the role of oral language and social functioning. Journal of Autism and Developmental Disorders, 43, 807-816. doi: 10.1007/ s10803-012-1619-4

Ricketts, J. (2011). Research review: reading comprehension in developmental disorders of language and communication. Journal of Child Psychology and Psychiatry, 52, 1111-1123.

Seidlová Málková, G., \& Smolík, F. (2014). Diagnostika jazykového vývoje [Diagnosis of Language Development]. Praha: Grada.

Snowling, M. (2000). Dyslexia. Malden: Blackwell Publishing.

Sotáková, H., Kucharská, A., Špačková, K., Presslerová, P., Richterová, E., \& Málková, G. (2014). Porozumění čtenému I/ [Reading comprehension II. Reading comprehension in children at risk for reading difficulties - background, topics, resources - critical analysis and research proposal]. Praha: PedF UK.

Thorová, K. (2006). Poruchy autistického spektra: Dětský autismus, atypický autismus, Aspergerův syndrom, dezintegrační porucha [Autism spectrum disorders: Childhood autism, atypical autism, Asperger syndrome, a disintegrating disorder]. Praha: Portál.

Wing, L., \& Potter, D. (2002). The epidemiology of autistic spectrum disorders: Is the prevalence rising? Mental Retardation and Developmental Disabilities Research Reviews, 8, 151-161.

Wildová, R. (2012). Rozvoj pregramotnosti a počáteční čtenářské gramotnosti $v$ kurikulu evropských zemí [Preliteracy development and early literacy in the curriculum of European countries]. Pedagogika, 62, 10-21.

Williamson, P., Carnahan, C. R., \& Jacobs, J. A. (2012). Reading comprehension profiles of high-functioning students on the autism spectrum: a grounded theory. Exceptional Children, 78, 449-469. 


\section{APPENDIX 1}

The six 'Strange Stories' employed in the study (O’Hare et al., 2009)

Lie (Dentist)

John hates going to the dentist because every time he goes to the dentist he needs a filling, and that hurts a lot. But John knows that when he has toothache, his mother always takes him to the dentist. Now John has bad toothache at the moment, but when his mother notices he is looking ill and asks him: "Do you have toothache, John?", John says: "No, Mummy".

1. Is it true what John says to his mother?

2. Why does John say this?

Social relations comprehension and text

Misunderstanding (Glove)

A burglar who has just robbed a shop is making his get-away. As he is running home, a policeman on his beat sees him drop his glove. He doesn't know the man is a burglar; he just wants to tell him he dropped his glove. But when the policeman shouts out to the burglar, "Hey you, comprehension in individuals stop!", the burglar turns round, sees the policeman, and gives himself up. He puts his hands up and admits that he did the break-in at the local shop.

1. Was the policeman surprised by what the burglar did?

2. Why did the burglar do this, when the policeman just wanted to give him back his glove?

Sarcasm (Picnic)

Sarah and Tom are going on a picnic. It is Tom's idea; he says it is going to be a lovely sunny day for a picnic. But just as they are unpacking the food, it starts to rain and soon they are both soaked to the skin. Sarah is cross. She says: "Oh yes, a lovely day for a picnic alright!".

1. Is it true what Sarah says?

2. Why does she say this?

Persuasion (Kittens)

Jill wanted to buy a kitten, so she went to see Mrs. Smith, who had lots of kittens she didn't want. Now Mrs. Smith loved the kittens and she wouldn't do anything to harm them, though she couldn't keep them all herself. When Jill visited she wasn't sure she wanted one of Mrs. Smith's kittens, since they were all males and she had wanted a female. But Mrs. Smith said: "If no one buys the kittens, I'll just have to drown them!".

1. Was it true what Mrs. Smith said?

2. Why did Mrs. Smith say this to Jill?

Pretend (Banana)

Katie and Emma are playing in the house. Emma picks up a banana from the fruit bowl and holds it up to her ear. She says to Katie: "Look! This banana is a telephone!".

1. Is it true what Emma says?

2. Why does Emma say this?

\section{Joke (Haircut)}

Daniel and Ian see Mrs. Thompson coming out of the hairdresser's one day. She looks a bit funny because the hairdresser has cut her hair much too short. Daniel says to Ian: "She must have been in a fight with a lawnmower!".

1. Is it true what Daniel says?

2. Why does he say this? 